\title{
ЖЕНЕ КОЈИХ ИМА У ДЕЛУ ИВЕ АНДРИЋА
}

\section{(Снежана Милојевић, Закон земле: Наратив о жени у прози Иве Андрића, Нови Сад: Акдемска књига, 2020)}

Навршио се читав век како читамо Андрића без дисконтинуитета у интересовању за његов стваралачки опус. Дела једног од најзначајнијих прозаиста српске књижевности 20. века не заобилазе ни, условно речено, нове стратегије читања, где се у другачијим методолошким оквирима његов приповедни свет отвара свежим значењима и увидима који потврђују Андрићеву приповедачку супремацију. Писац који је успео да се научничком преданошћу у детаљном испитивању грађе и спонатном приповедачком делатношћу посвети свим великим темама, успешно је градио мостове између универзалних идеја и сасвим специфичних прича везаних за конкретно време и место. Херменеутички показујући како се опште пресликава у посебно, а посебно потврђује у општеважећем, посветио је много пажње не само педантној изградњи женских ликова, већ и женском принципу и дискурсу о жени, преплићући онтолошко, поетичко и искуствено.

Снежана Милојевић по звању припада медиевалистима, што потвруђује не само њена докторска дисертација, већ и раније објављена монографска студија Од премудрих чула (2017), као и низ научних радова из области српске средњовековне књижевности. Поред тога, у више наврата се бавила Андрићевим стваралаштвом, што је резултирало и објављивањем двеју многорафија посвећених делу овог великана српске књижевности. Књизи Медитативна проза Иве Андрића (2008) уследила је Закон земље (2020). Овај континуитет бављења Андрићевим стваралаштвом указује на друго жариште научног интересовања ауторке која је читалачкој публици позната и као прозна списатељица збирке прича Градић Смејтон (2011) и књиге путописне прозе Оријентални Мефбито и други путописи (2015).

Монографија Закон земље организована је као колекција ауторкиних раније публикованих радова о Андрићевом опусу, које је написала као дугогодишња учесница пројекта „Иво Андрић у европском контексту” Катедре за славистику Универзитета „Карл Франц” у Грацу и као стална сарадница Задужбине Иве Андрића у Београду. У том смислу, 
текст ове књиге два пута је пролазио кроз руке еминентних истраживача Андрићевог стваралаштва, будући да су њени делови, као посебна целовита истраживања, већ публиковани у зборницима радова и у научним часописима. Њихово окупљање у оквиру једне монографије оправдано је проблематиком коју је ауторка отварала у низу Андрићевих дела, а која се може покрити метафором „закона земље”, одабраном и за наслов ове публикације.

„Закон земље” као синтагма-сигнум преузет је из медитативне прозе Иве Андрића (Exponto), не би ли се упутило на разорну и незаустављиву моћ инстинкта путености који замрачује моћ расуђивања и онеспокојава и најмудрији ум (10). Нагонска телесна природа људског бића којој је немогуће одупрети се одређује начин функционисања и мушких и женских ликова. Овако ауторка мотивише стожер око којег окупља интерпретације оних Андрићевих дела где женски ликови не морају бити у средишту неприкосновене приповедачеве пажње, али где ипак отварају могућности значењског гранања или допунавања централне идеје од које је кренула.

У девет поглавља, колико књига садржи, ауторка је себи дозволила методолошки плурализам када је у питању перспектива читања. Сами појединачни текстови „бирали” су начине на које их ваља тумачити, односно методолошке оквире у које их треба поставити. Иако се према корпусу текстова за који се определила, као и према самој тематско-мотивској окосници, може наслутити на доминацију приступа из угла феминистичке или гинокритике, ауторка је одабрала да систем своје истраживачке апаратуре усмери и ка наратолошкој, психоаналитичкој (Фројд, Јунг, Лакан), деконструктивистичкој, имаголошкој теорији, као и према теорији интертекстуаности и теоријама могућих светова, не запостављајући анализе дискурса о жени ниједног тренутка. У сваком од поглавља није одсутала ни од указивања на основне елементе Андрићеве комплексне ауторске поетике, коју, између осталих, одређује ослањање на мит или употреба префињене ироније као средства за депатетизацију, те разбијање клишеа, предрасуда и устаљених облика поимања и вредновања.

Предговор јасно упућује на то шта у књизи треба очекивати и функционише као својеврстан сажетак и хипотеза и закључака. Та самосвест уродила је плодом у свакој истраживачкој и стваралачкој етапи. Добро познавање релевантне литературе уочавамо не само када је теоријска основа у питању, већ и када говоримо о књижевникритичарској и књижевноисторијској рецепцији Андрићевог дела. Милојевић издваја најзначајније огледе и студије о Андрићевом опусу, а нарочито оне које се односе на проучавање лепоте и женских ликова, будући да су код Ан- 
дрића често у тесној вези (чувена коб женске лепоте), а то су: „Исток у приповеткама Иве Андрића" Исидоре Секулић, Лепа бића Иве Андрића Драгана Стојановића, „Жена у Андрићевим приповијеткама” Станка Кораћа, „Женски ликови у делу Иве Андрића” Тони Ливерсејџ, „Опсесија телом као последица прихватања мушке визуре жене: Андрићева Жена на камену" Дубравке Срдановић Поповић итд.

Централна проблематика се посматра у две, по форми различите, групе Андићевих текстова. У романима На Дрини ћуприја, Травничка хроника и Госпођица, а потом и у приповеткама, и то у оним које не активирају класичан Андрићев хронотоп везан за одређен просторни, временски, нацонални и верски оквир (мултинационална и мултиконфесионална Босна): „Жена од слонове кости”, „На стадиону”, „Игра”, „Жена на камену”, „Јелена, жена које нема”, „Кнез са тужним очима”, „Бајрон у Синтри”. У овим приповеткама се још боље види универзалност проблематике, али и комплексни метод којим јој Андрић у обради приступа, а одабир приповедачког корпуса заснован је и на ауторкином ставу да се у њима боље уочава мушка свесност о женској снази. Жене код Андрића могу представљати калокагатијски спој памети и лепоте, али има и оних жена које су познате по гротексном мешању женскости и нечег мушкобањастог, гледано из традиционалне патријархалне перспективе одређивања ових појмова, те отуда постоји и посебно интересовање за оне жене (попут Лотике) код којих је присутан спој ових особина. Ауторка заузима вредносно неутралан став према овом стереотипу и више га констатује него што га анализира, док своја истраживања настоји да усмери ка мање анализираним или потпуно неоткривеним детаљима у Андрићевом причању о женама и женском (принципу).

У читању романа На Дрини ћуприја проблематизује се мит о жени као извору мушке чежње, док је она представљена као пуна тајни, недохватљива, недодирљива, хировита, склона прекорачењу социјаних узуса. У роману Травничка хроника приступа се много комплекснијем проблему нарцисоидности Ане Марије фон Митерер, која је патила од вишка фантазије и незајажљиве потребе за одушевљењем. Као централни део представљена је индивидуална и колективна хистерија (затварање чаршије), где паралелнно стоје досада и бес у жени и досада и бес у вароши „која упада у своја ирационалана стања као у какав транс”, а он „траје одређено време и стишава се наједном” (47). Лепо је уочена иронија према љубавном роману тј. деконструкција жанра љубавног романа за који је послужила слика жене, док су сами манични поремећаји објашњени психоаналитичким приступом лакановског типа кроз однос реалног, имагинарног и симболичког. Роман Госпођица и лик Рајке Радаковић читан је кроз принцип разлике и културолошки концепт другости. У пр- 
вом плану проблематизована је особина неженствености. Из угла феминистичке критике отвара се проблем женствености као фетишизације и деградације жене. Лик главне јунакиње виђен је кроз њену неприпадност типизираном и патријархалном концепту женствености. Хладна попут мушкарца, стара девојка, она је у подразумевани концепт женствености неуклопива. Сусрет са самом собом јунакиња остварује у додиру са речима других који је тако описују. У Проклетој авлији анализира се наратив о жени, пошто се оне у овом роману не појављују као делатни ликови, већ само у причама непоузданих приповедача. Служећи се класичним наратолошким приступом (Женет, Бут), ауторка је анализирала различите облике мушког дискурса о жени, а кроз њих и посебне стереотипе о жени са којом се живи, жени домаћици и жени мајци. Из перспективе која би највише одговарала пракси феминистичке дискурзивне анализе, читају се и „жена-тело” и „жена-жеља”, које и јесу оваплоћење мушке тенденције ка поседовању.

Анализу приповедака диктирао је, такође, сваки појединачни текст. Један од најинтересантнијих делова монографије посвећен је интерпретацији приповетке „Жена од слонове кости”, којој се приступа из неколико углова. Прича се најпре посматра у оквиру фантастике, тачније као Андрићева иронизација фантастичних прича. Затим и кроз медицински и психолошки феномен „парализе сна”, да би се на крају сагледала кроз, опет иронично, разбијање стереотипа, мита, представе о мушкарцу који је уплашен да ће са женом (уз жену) изгубити слободу, док је истовремено жели јер је под дејством латентног страха од самоће. У основи је иронизација клишеа, схватања по коме жена жели да задржи мушкарца који зато покушава да побегне од ње, где страх од блискости постаје симптом епохе у којој живимо.

Тумачење трију приповедака: „Жена на камену”, „На стадиону” и „Игра” резултира увидом да ту: „[...]жена није неко ко је неактиван и ко из своје статичке позиције изазива и покреће мушки свет на најразличитије неподопштине нити је пак супротност статичној жени - пошаст која обезнањује мушкарце њоме занесене, већ самосвесна слободна жена која јасно исказује свој став, своје жеље и настојања." (127) Међутим, долазак старости код Марте („Жена на камену”) резултира поновним раздвајањем тела и духа који су били у складу и сагласју и указује на истрајавање деловања тзв. „мушког мишљења”, на шта у својој завршној синтези ауторка скреће пажњу.

Тајанствено присуство/одсуство жене у поетској фантастици приповетке „Јелена жена које нема”, разоткрива се најпре посредством Фројдовог концепта „језе” (Das Unheimliche), где нешто што је познато и што се доживљавало као блиско, постаје страно и зачуђујуће. Поред пре- 
гледа тумачења Предрага Палавестре, Мирослава Радовановића, Тихомира Брајовића, Анта Башића и других, ауторка се усмерава и ка јунговском тумачењу нестварне жене као аниме. Поред тога, Јеленино писмо, оно којим се директно оглашава, упућује на могућа тумачења у смеру француске феминистичке постструктуралистичке критике Елен Сиксу да жена писањем ствара себе. Овакав вид разматрања највише нас води ка гинокритици, те ауторка указује да Андрићева приповетка антиципира теорије о женском писму. У вишегласју неколико различитих приступа издваја се и сасввим упечатљив закључак да: „[...] тачка преклапања између самосвесне Јелене и типичне жене патријархата јесте да су обе невидљиве - прва зато што не инсистира на свом интегритету, друга зато што је досегла целовитост (прва зато што је мушкарчева сенка, а друга зато што излази из ње - налази се иза његове сенке)." (148-149)

Приповетка „Кнез са тужним очима”, где се жена реализује као тело и деструира читав систем мале идиличне кнежевине, преиспитује још један уврежени мит о жени као латентној опасности. Успостављена интертекстуална мрежа са античким митовима и Библијом (Пандора, Ева, Нарцис), реплицира мушке слике о жени као потенцијалној опасности. Иронијом и пародијом Андрић се и овде одваја од тада доминантних образаца и отвара ка високом модернизму.

Посредством Долежелове теорије могућих светова, ауторка чита приповетку „Бајрон у Синтри”, где чувени романтичарски песник функционише као транссветовни идентитет и гради се веза између Бајрона као стварне личности и лика који је представљен у свету фикције. Његов сусрет са девојчицом-женом, оваплоћењем природе саме, споја етички лепог и естетски лепог, покренуо је „неочекивану трансформацију Бајронове есенцијалне особине, његовог стриктног означитеља - сладострашћа" (179). Она се јавља као муза Бајронове трансформације, где естетски лепо врши етички преображај: као „[...]парадигма примитивног и анималног (мало створење) бива мотивација идентификовања и учвршћивања етичко-естетског односа према жени" (188-189). Стање преображаја је веома кратко трајало. Као и у приповеци „Аска и вук” изостаје кључно приповедачево (или Андрићево) поверење у трајну снагу уметности и етичког преображаја до којег је она могла довести.

У књизи Снежане Милојевић, где не недостаје поглавље које би се могло схватити као закључак или сума појединачних закључака, јер је све то већ речено у Предговору, анализирани су различити типови дискурса, прича о женама, оптерећени традиционалном свешћу патријархалне културе којем су жене као јунакиње припадале. Али се са друге стране, оне појављују и као етерична фантастична бића, где је реални супстрат до краја испражњен, не би ли се дошло до њиховог симболичког 
оваплоћења у контексту модернистичке традиције. У књизи је остварен и дијалог између Андрићевог приповедног и медитативног, што повезује два жаришта када је у питању ауторикино досадашње интересовање за дело нашег нобеловца.

Јелена С. Младеновић

Универзитет у Нишу

Филозофски факултет

Департман за србистику

jelena.mladenovic@filfak.ni.ac.rs 